Article

\title{
Impacts of Water Resources Allocation on Water Environmental Capacity under Climate Change
}

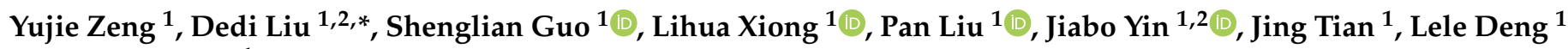 \\ and Jiayu Zhang ${ }^{1}$ \\ 1 State Key Laboratory of Water Resources and Hydropower Engineering Science, Wuhan University, \\ Wuhan 430072, China; yujiezeng@whu.edu.cn (Y.Z.); slguo@whu.edu.cn (S.G.); xionglh@whu.edu.cn (L.X.); \\ liupan@whu.edu.cn (P.L.); jboyn@whu.edu.cn (J.Y.); jingtian@whu.edu.cn (J.T.); leledeng@whu.edu.cn (L.D.); \\ Jiayu_Z@whu.edu.cn (J.Z.) \\ 2 Hubei Province Key Lab of Water System Science for Sponge City Construction, Wuhan University, \\ Wuhan 430072, China \\ * Correspondence: dediliu@whu.edu.cn
}

check for updates

Citation: Zeng, Y.; Liu, D.; Guo, S.; Xiong, L.; Liu, P.; Yin, J.; Tian, J.; Deng, L.; Zhang, J. Impacts of Water Resources Allocation on Water Environmental Capacity under Climate Change. Water 2021, 13, 1187. https://doi.org/10.3390/w13091187

Academic Editor: Athanasios Loukas

Received: 2 April 2021

Accepted: 22 April 2021

Published: 25 April 2021

Publisher's Note: MDPI stays neutral with regard to jurisdictional claims in published maps and institutional affiliations.

Copyright: (c) 2021 by the authors. Licensee MDPI, Basel, Switzerland. This article is an open access article distributed under the terms and conditions of the Creative Commons Attribution (CC BY) license (https:/ / creativecommons.org/licenses/by/ $4.0 /)$.

\begin{abstract}
Water environmental capacity (WEC) is an essential indicator for effective environmental management. The designed low water flow condition is a prerequisite to determine WEC and is often based on the stationarity assumption of low water flow series. As the low water flow series has been remarkably disturbed by climate change as well as reservoirs operation and water acquisition, the stationarity assumption might bring risk for WEC planning. As the reservoir operation and water acquisition under climate change can be simulated by a water resources allocation model, the low water flow series outputted from the model are the simulations of the disturbances and often show nonstationary conditions. After estimating the designed low water flow through nonstationary frequency analysis from these low water flow series, the WEC under the nonstationary conditions can be determined. Thus, the impacts of water resources allocation on WEC under climate change can be quantitatively assessed. The mid-lower reaches of the Hanjiang River basin in China were taken as a case study due to the intensive reservoir operation and water acquisition under the climate change. A representative concentration pathway scenario (RCP4.5) was employed to project future climate, and a Soil and Water Assessment Tool (SWAT) model was employed to simulate water availability for driving the Interactive River-Aquifer Simulation (IRAS) model for allocating water. Water demand in 2016 and 2030 were selected as baseline and future planning years, respectively. The results show that water resources allocation can increase the amount of WEC due to amplifying the designed low water flow through reservoir operation. Larger regulating capacities of water projects can result in fewer differences of WEC under varied water availability and water demand conditions. The increasing local water demand will decrease WEC, with less regulating capacity of the water projects. Even the total available water resources will increase over the study area under RCP4.5. More water deficit will be found due to the uneven temporal-spatial distribution as well as the increasing water demand in the future, and low water flow will decrease, which further leads to cut down WEC. Therefore, the proposed method for determining the WEC can quantify the risk of the impacts of water supply and climate change on WEC to help water environmental management.
\end{abstract}

Keywords: water environmental capacity; water resources allocation; climate change; nonstationary; Hanjiang River basin

\section{Introduction}

With the increasing population and rapid expansion of industry and agriculture, an enormous amount of sewage has been drained into rivers and aggravated the deterioration of water quality, which has resulted in serious water pollution [1,2]. In order to alleviate water deterioration and safeguard water use, a water quality control scheme is implemented according to the water quality protection target. Water environmental capacity (WEC) 
indicates the yearly total maximum pollutant load that is permitted to drain into river without water quality deterioration in water quality control scheme. WEC is often taken as an indicator for the sustainable development and the ecological stability $[1,3,4]$. The amount of WEC is not only determined by the water quality protection target, but also dependent on the designed low water flow. The designed low water flow is often chosen by the minimum monthly average water flow with an annual exceedance probability $[5,6]$ or the seven-day average low flow within a $T$-year return period $[7,8]$. Thus, the designed low water flows are determined by frequency analysis that are often based on historical natural low water flow series and its stationarity assumption. As the stationary assumption has been violated by human activities or climate change, a lot of new hydrological frequency analyses for nonstationary conditions have been developed. Cooley eschewed the term return period and instead communicates yearly risk in terms of a probability of exceedance to investigate return level for hydrological extremes under nonstationary climates [9]. Du et al. improved the characterization of the nonstationary return period and risk under the expected number of exceedances interpretation by employing meteorological covariates in the nonstationary frequency analysis [10]. Rootzén and Katz proposed the design life levels for quantifying the probability with exceeding a fixed threshold for nonstationary climates [11]. Obeysekera et al. adopted the expected occurrence frequency of a given hydrological extreme under nonstationary climates for projects designs [12]. However, few of them have simultaneously considered the impacts of climate change and human activities (i.e., reservoirs operation and water acquisition) on the designed low water flow, which probably brings risk for the planning of water environmental management.

As climate change is considered as one of the main driving forces for the variation of water flow [13,14], the temporal-spatial distribution of available water resources will become more uneven under future scenarios [15-17], which will bring daunting challenges in water supply and cause water deficit problems, especially on the boundary areas of a basin [18]. The variation of available water resources is prone to lead great impacts on low water flow series and its designed low water flow conditions for WEC [19]. Even the responses of runoff to climate change have been concerned [20,21], the impacts of human activities on low water flow series are rarely discussed. As the amount of water supply is dependent on the water project (e.g., reservoir) operational rules, the temporalspatial distribution of natural water flow for water availability can also be altered by water projects operation [22]. With the operation of reservoirs, the connections between water flows at different locations have been disturbed, resulting in the nonstationary time-varying marginal distributions between different hydrological series [23], especially for the low water flow series. With the rapid expansion of industry and agriculture in the future, the water demand will dramatically increase $[24,25]$ and intensify the alteration of water flow, which alters the stationary assumption of low water flow series frequency analysis for the designed low water flow. Therefore, the impacts of climate change and human activities on low water flow series and the designed low water flow should be assessed.

The water resources allocation model simultaneously incorporates the water projects operation including reservoirs operation and water acquisition for water allocation [26]. The water resources allocation model has become an effective tool for quantitatively assessing the impacts of climate change and human activities on low water flow series and the designed low water flows [27-29] and further the impacts on WEC. The aim of our study is to propose a framework for estimating WEC under the nonstationary low water flow conditions that are caused by climate change as well as reservoir operation and water acquisition. The remainder of this paper is organized as follows: Section 2 introduces the framework for assessing the impacts of water resources allocation on WEC under climate change. Section 3 describes the methodologies applied in mid-lower reaches of Hanjiang River basin in China. Section 4 represents the results of projected water availability, water demand, water resources allocation, designed low water flow under stationary and nonstationary conditions and their corresponding WECs. The impacts of 
water resources allocation on WEC have also been discussed in this section. Section 5 gives the conclusions.

\section{Methodology}

2.1. Framework for Assessing the Impacts of Water Resources Allocation on Water Environmental Capacity under Climate Change

The framework for assessing the impacts of water resources allocation on WEC under climate change can be divided into four main modules (shown in Figure 1): (1) water availability estimation module, (2) water demand projection module, (3) water resources allocation module and (4) water environmental capacity determination module.

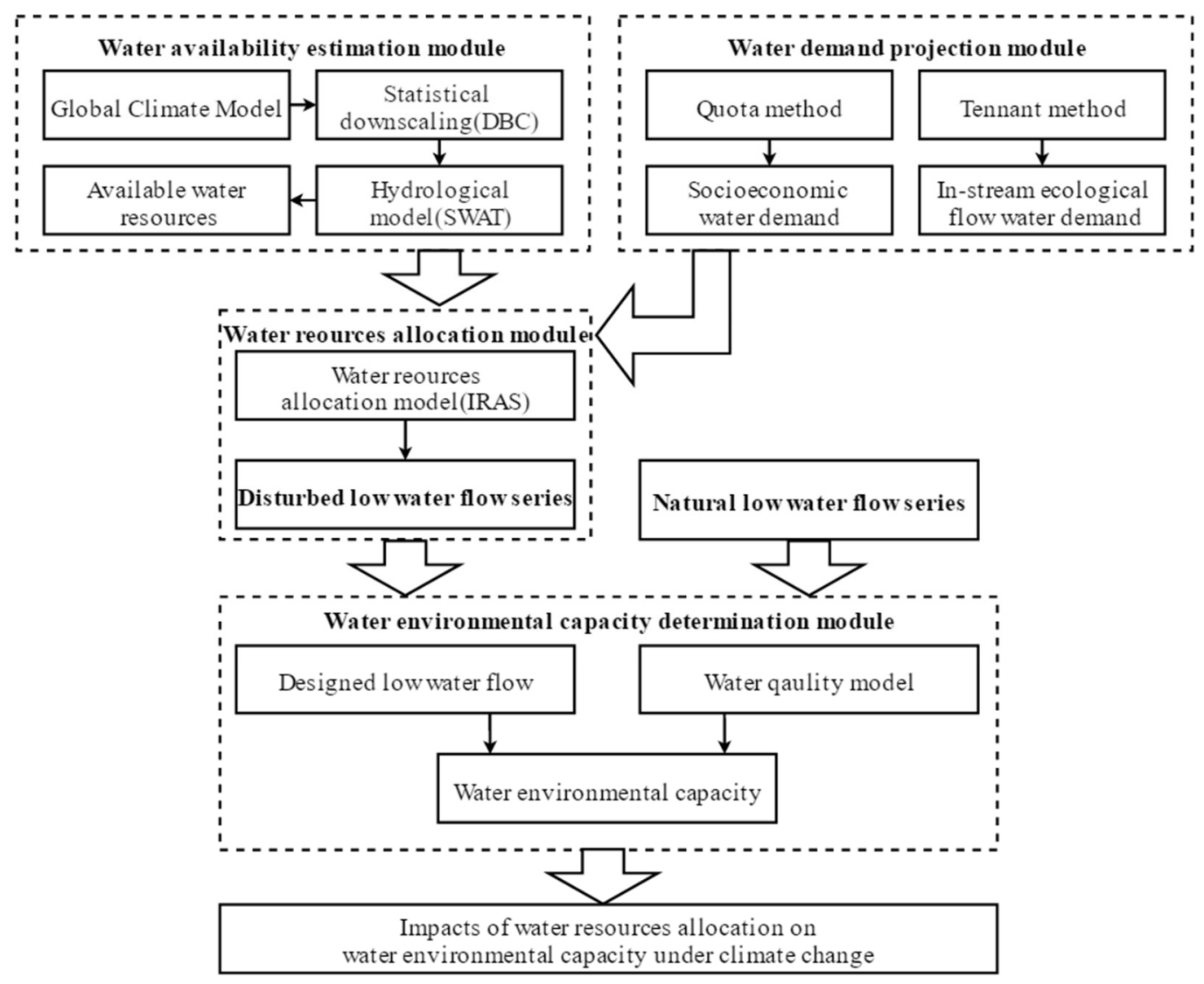

Figure 1. A framework for assessing impacts of water resources allocation on WEC under climate change.

The function of the water availability estimation module is estimating the water availability under historical and future scenarios. As the outputs of the General Circulation Model (GCM) have been widely used across the world for projecting the future climate [30,31], they are inputted into Soil and Water Assessment Tool (SWAT) hydrological model for predicting the water availability in the future. In order to adjust the outputs of large scale GCM for satisfying the inputs of the small-scale SWAT model, an effective statistical downscaling method (i.e., Daily Bias Correction (DBC) method) is adopted in this module [32]. The DBC method takes into account the different changes in frequency distributions of daily precipitation, and corrects the wet-day frequency of precipitation by using a small precipitation threshold [32]. The water demand module is composed of the quota method and the Tennant method. The quota method is used for projecting the water demand in socioeconomic use sectors in the planning year, and the Tennant method can determine the water demand of in-stream ecology [33,34]. The function of the water resources allocation module is to deploy water resource to every water use sector according to their water demands and water availabilities. The Interactive River-Aquifer Simulation 
(IRAS) model is adopted here due to its flexibility and accuracy in simulation [35]. The disturbed low water flow series outputted from water resources allocation module and the natural low water flow series will be taken as the inputs to determine the designed low water flow for water environmental capacity determination module [36]. Based on the designed low water flows, the impacts of water resources allocation on WEC under climate change will be figured out.

\subsection{Water Availability Estimation Module}

The hydrological model is considered as the most effective tool to assess the available water resources under different climate scenarios. The SWAT model is developed by the Agricultural Research Service of the United States Department of Agriculture and has become one of the most popular distributed hydrological models around the world $[37,38]$. Hydrological response unit (HRU) is the basic unit in SWAT model. The routine of water is simulated from the HRUs to the sub-basin level according to the daily water cycles. SWAT model has been proved to be an excellent tool for accessing the impacts of climate change on runoff $[39,40]$. In order to project the future water resources through SWAT at basin scale, outputs from the GCMs at global scale [41,42] are downscaled by DBC method to derive empirical relationships between the global scale GCM predictors and the basin-scale predictors [32]. Therefore, DBC method and SWAT model are the primary tools for water availability estimation.

\subsection{Water Demand Projection Module}

Water uses are often classified into socioeconomic (also called off-stream) use and in-stream ecology use in a water allocation model. Socioeconomic use consists of municipal, rural, industrial, agricultural categories in the water demand projection module.

\subsubsection{Socioeconomic Water Demand}

Quota method is widely applied to project the annual socioeconomic water demand in a planning year [43]. The amounts of water demand for the four water use sectors can be obtained by Equation (1).

$$
W d_{i, j}^{t}=W q_{i, j}^{t} \times A_{i, j}^{t} / U R_{i, j}^{t}
$$

where $W d_{i, j}^{t}$ is the amount of water demand for the $j$ th use sector in the $i$ th operational zone at the $t$ th time step; $W q_{i, j}^{t}$ is the water quota unit of water demand use sector; $A_{i, j}^{t}$ is the amount of water units in water use sector; $U R_{i, j}^{t}$ is the utilization rate of water use sector. The water quota units are the amount of water consumption per capita in municipal and rural use sectors, the amount of water consumption per ten thousand Yuan in industrial use sector and the amount of net irrigation water per unit area in agricultural use sector, respectively; the number of water units are the projected population in municipal and rural use sectors, the projected GDP in industrial use sector and the projected irrigated area in agricultural use sector.

\subsubsection{In-Stream Ecology Water Demand}

The in-stream ecological flow is taken account to protect the local ecological environment satisfying the ecological use and to support the survival of aquatic wildlife in operational zones. Tennant method, a popular method to estimate in-stream ecological water demand [34,44], is applied through the product of the annual average runoff and proportions during the flood season and non-flood season:

$$
W d e_{i}^{t}=R_{i} \times \varepsilon_{i}
$$


where $W d e_{i}^{t}$ is the in-stream ecological water demand in the $i$ th operational zone at the $t$ th time step; $R_{i}$ is the average annual runoff; $\varepsilon_{i}$ is the proportion coefficient of minimum ecological environment water demand.

\subsection{Water Resources Allocation Module}

Based on the outputs from water availability estimation module and water demand projection module, water resources allocation module will deploy the available water resources to every water use sector and the in-stream water flow along with river segments. Developed by Cornell University [45], IRAS is a rule-based water system simulation model for water resources allocation and is adopted here due to its flexibility and accuracy in simulation [35].

As the water system is often composed of water transfer, consumption and loss components, it can be sketched by node network topology. Two types of nodes, named the reservoir node and demand node, play vital roles and are directly corresponding to the "supply-side" and "demand-side", respectively. Water release from reservoir node is based on the reservoir operation rules while the water deficit at demand node can be estimated by the following water balance Equations (3) and (4).

$$
\begin{aligned}
W_{s t}^{e} & =\sum_{1}^{s t} W_{s t}^{i n}-\sum_{1}^{s t} W_{s t}^{d} \times \frac{(t s t-s t+1)}{(s t-1)} \\
W_{s t}^{d} & =\frac{W_{t}^{d e m}-W_{t}^{d e m} \times f-\sum_{1}^{s t} W_{s t}^{i n}-W_{s t}^{e}}{t s t-s t+1}
\end{aligned}
$$

where $t$ is the current time step; tst is the total number of the sub-time-step; st is the current sub-time-step; $W_{s t}^{e}$ is the amount of water from natural inflow; $W_{t}^{\text {dem }}$ is the water demand of the water use sector; $f$ is the demand reduction factor; $W_{s t}^{d}$ is the water deficit.

\subsection{Water Environmental Capacity Determination Module}

The disturbed low water flow series can be derived from water resources allocation module while the natural low water flow series can be selected from observed data or from the simulated runoff by SWAT model. The minimum monthly average water flow with an annual exceedance probability of $90 \%$ is defined as the designed low water flow for WEC. WEC in every river segment with their corresponding water quality protection target $C_{s}$ can be estimated by Equation (5).

$$
E=\left(C_{s} \times e^{k x / u)}-C_{0}\right)\left(Q_{0}+q\right)
$$

where $E$ is WEC in a river segment; $C_{s}$ is the water quality protection target; $C_{0}$ is pollutant background concentration; $k$ is the pollutant attenuation coefficient; $x$ is the river segment length; $u$ is flow velocity related to the designed low water flow; $Q_{0}$ is the designed low water flow; $q$ is water flow from the sewage.

\section{A Case Study in Mid-Lower Reaches of Hanjiang River Basin}

\subsection{Study Area}

The mid-lower reaches of Hanjiang River basin is located in the Hubei province of central China (shown in Figure 2), and its area is about $63,800 \mathrm{~km}^{2}$. The water from the upper reaches of basin flows into the Danjiangkou reservoir and then releases into the study area. The Danjiangkou reservoir is the water source of the middle route of the south-north water transfer project in China [46], our study area has been impacted by both climate change and water acquisition from the water transfer project. Moreover, due to the fast urbanization and the rapid development of the economy, the local water demand is increasing, and water quality is deteriorating. Therefore, the impacts of climate change and 
human activities on WEC should be assessed for sustainable development and ecological environment protection.

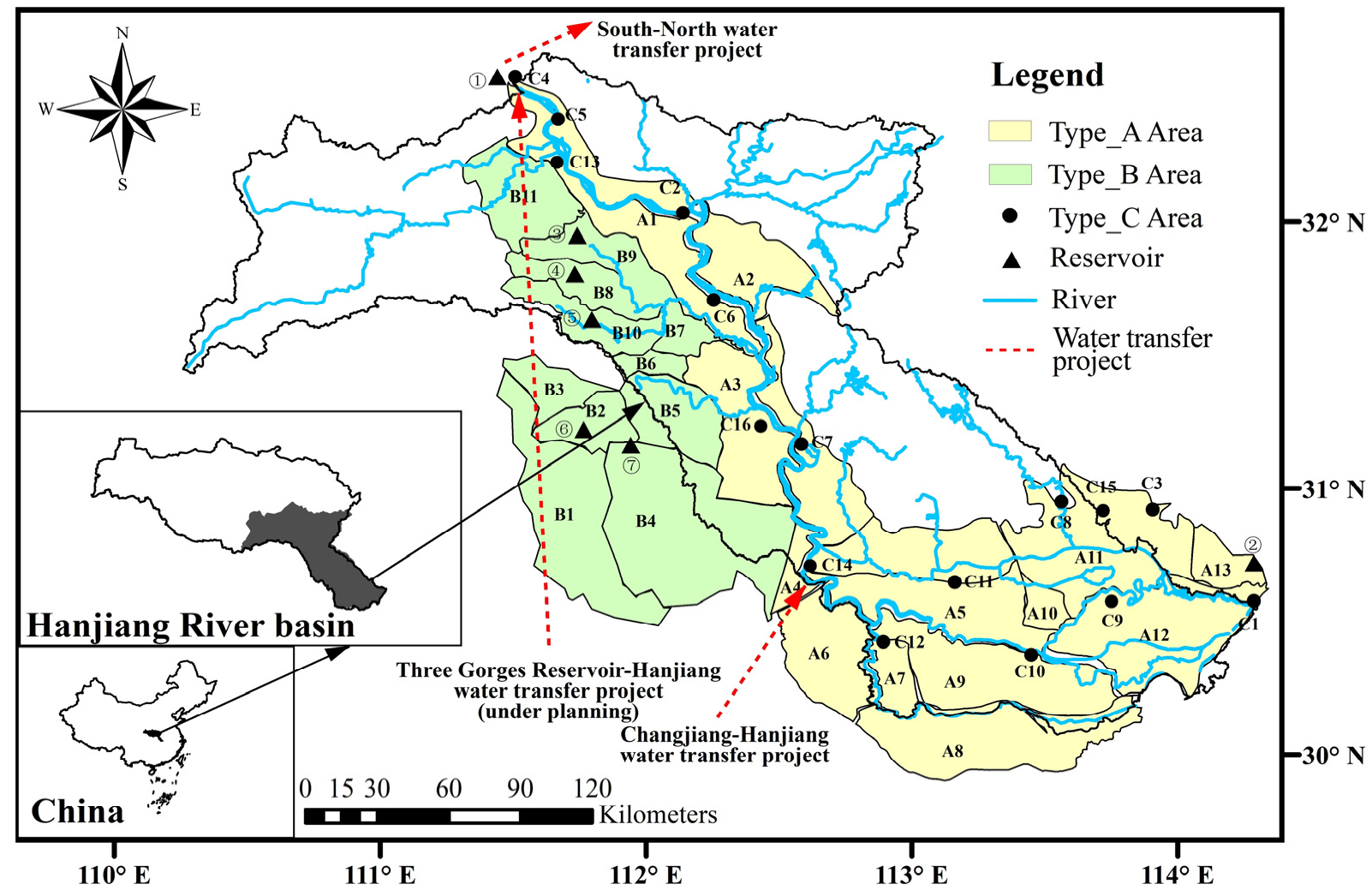

Figure 2. Location of the mid-lower reaches of the Hanjiang River basin, China.

According to the main water use and its water sources, the study area can be classified into three types: type $A$ that is the irrigation area and acquires water from the mainstream of the Hanjiang River; type B that is also the irrigation area which diverts water from the mainstream of Changjiang River through the Three Gorges Reservoir-Hanjiang water transfer project (under planning); type $C$ that is cities while acquires water from the mainstream of Hanjiang River. 40 operational zones are sketched based on the local water systems, and there are 13, 11 and 16 operational zones in type A, B and C, respectively. There are seven medium or large size reservoirs (the total storage volume is 36.7 billion $\mathrm{m}^{3}$ ) for regulating water flows (shown in Figure 2). In order to illustrate the connections between operational zones and river systems in IRAS model, the water system can be sketched as Figure 3. 


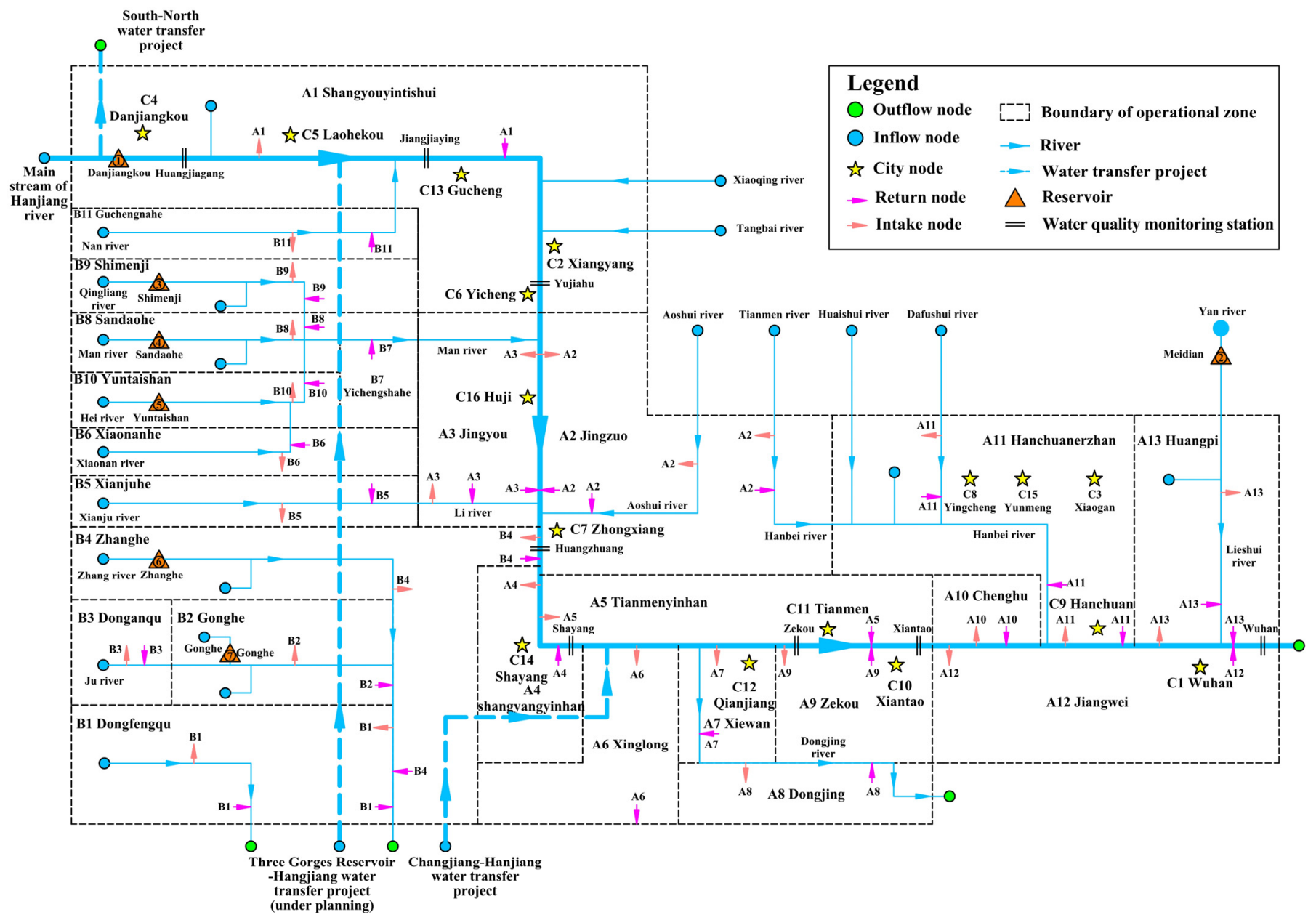

Figure 3. Sketch of the water system for the mid-lower reaches of the Hanjiang River basin.

\subsection{Description of Water Demand and Availability Schemes}

To figure out the potential impacts of water resources allocation on WEC, six schemes are set according to the varied water availability and water demand conditions (shown in Table 1). The schemes I, II, III and IV are set by the combination of two water availability scenarios (i.e., history and future) and water demands in baseline (2016) and planning years (2030). In order to figure out the impacts of human activities on the WEC, schemes V and VI with historical and future natural water flows are set as reference schemes without water resources allocation.

Table 1. Water demand and water availability schemes for determining WEC.

\begin{tabular}{ccc}
\hline Scheme & Water Resources Allocation & Description \\
\hline I & Yes & History of water availability and water demand in 2016 \\
II & Yes & History of water availability and water demand in 2030 \\
III & Yes & Future of water availability under RCP4.5 and water demand in 2016 \\
IV & Yes & Future of water availability under RCP4.5 and water demand in 2030 \\
V & No & History of natural water flow series \\
VI & No & Future of natural water flow series under RCP4.5 \\
\hline
\end{tabular}

\subsection{Data Set}

\subsubsection{Hydrological Data}

The daily precipitation and daily maximum and minimum air temperatures data from 1961 to 2005 are obtained from 25 meteorological gauging stations in the Hanjiang River 
basin, which are provided by China Meteorological Administration. 261 precipitation gauging stations charged by the Bureau of Hydrology affiliated to the Changjiang Water Resources Commission have also provided daily precipitation data from 1980 to 2000 to drive SWAT model. The daily discharge data from four runoff gauging stations from 1980 to 2000 are also collected. The outputs from the Beijing Climate Center Climate System Model (BCC-CSM) under the representative concentration pathway RCP4.5 scenario are adopted to project future climate change, due to its good performance in reproducing observed climate variations of temperature and precipitation in China [47].

\subsubsection{Socioeconomic Water Demand Data}

Water consumption ratios, social and economic development projection for each operational zone in the baseline year (2016) and planning year (2030) are provided by the Hubei Provincial Department of Water Resources. Their water demands are projected by water demand projection module. Water uses in operational zones in type $C$ area are only municipal and industrial uses while there are four types of water use in the operational zones in type A and type B areas. The water flow data for estimating in-stream water flow demand are outputted from the SWAT model.

\subsubsection{Characteristics of Reservoirs}

The characteristics of the seven reservoirs are listed in Table 2 and their operation rules are collected from the dispatching schedules of Hubei provincial large reservoirs compiled by Hubei Provincial Department of Water Resources [48].

Table 2. Characteristics of the middle or large size reservoirs (million $\mathrm{m}^{3}$ ).

\begin{tabular}{cccccc}
\hline No. & Name & Total Storage & Storage at Normal Water Level & Dead Storage & $\begin{array}{c}\text { a Storage at Flood } \\
\text { Limiting Water Level }\end{array}$ \\
\hline (1) & Danjiangkou & 33,910 & 29,050 & 12,690 & $22,910 / 25,790$ \\
(2) & Meidian & 162 & 87 & 31 & 87 \\
(3) & Shimenji & 154 & 115 & 2 & 99 \\
(4) & Sandaohe & 155 & 127 & 0 & 127 \\
(5) & Yuntaishan & 123 & 89 & 5 & 89 \\
(6) & Zhanghe & 2023 & 924 & 1 & 865 \\
(7) & Gonghe & 173 & 105 & 865 & 84 \\
\hline
\end{tabular}

a There are two flood limiting water levels during the summer and autumn flood seasons in Danjiangkou reservoir.

\subsubsection{Water Quality Data}

Water quality data from the nine gauge stations along the mainstream are obtained from Hubei Provincial Department of Water Resources to force the water environmental capacity determination module. These nine stations divide the main stream into eight river segments (shown in Figure 4). Chemical oxygen demand $\left(\mathrm{COD}_{\mathrm{Mn}}\right)$ and ammonium nitrogen $\left(\mathrm{NH}_{3}-\mathrm{N}\right)$ are taken as water quality indicators according to the water quality control scheme. The total actual pollution discharges of $\mathrm{COD}_{\mathrm{Mn}}$ and $\mathrm{NH}_{3}-\mathrm{N}$ in eight segments in 2016 were obtained from the environmental pollution source investigation report provided by Hubei Environmental Protection Bureau [49]. The total discharge of $\mathrm{COD}_{\mathrm{Mn}}$ and $\mathrm{NH}_{3}-\mathrm{N}$ in 2016 are 307,209 $\mathrm{t}$ and $8961 \mathrm{t}$, respectively. According to the technical guideline of environmental capacity of surface water in China complied by the Chinese Academy for Environmental Planning [50], the parameter $k$ for $\mathrm{COD}_{\mathrm{Mn}}$ and $\mathrm{NH}_{3}-\mathrm{N}$ are set to be 0.25 and 0.10 , respectively. 


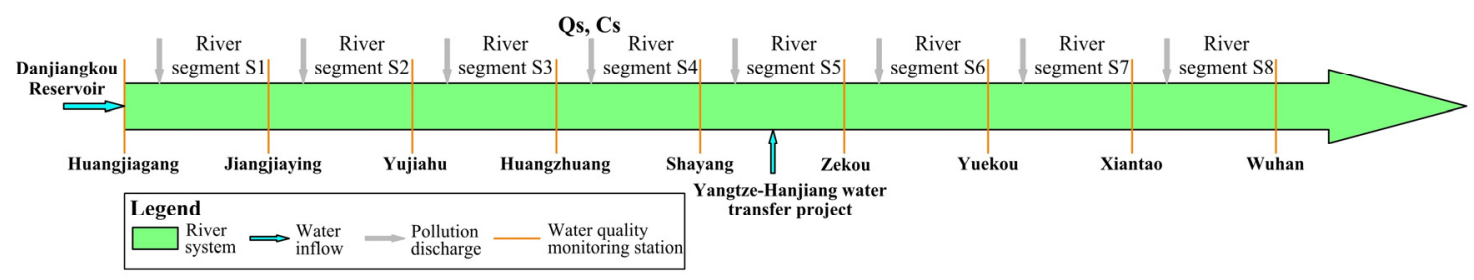

Figure 4. River segments in the main stream of the mid-lower reaches of the Hanjiang River.

\section{Results and Discussion}

\subsection{Water Availability under Historical and Future RCP4.5 Scenarios}

In order to project the future water availability, the DBC method is calibrated firstly by historical data. The relative errors of precipitation are less than $15 \%$ and the absolute errors for maximum and minimum temperature are less than $1.5^{\circ} \mathrm{C}$, so the calibrated DBC can be applied in downscaling future precipitation and surface temperature. The SWAT model is calibrated and validated by the daily discharge data under historical scenario from 1980 to 2000. The period (1980-2000) is split into calibration period (1980-1993) and validation period (1994-2000), respectively. The Nash-Sutcliffe efficiency coefficient (NSE) values for hydrological simulation at the four runoff gauging stations are listed in Table 3. The NSE values during the calibration and validation periods range from 0.66 to 0.93 , suggesting that the calibrated SWAT model can apply to project the future runoff.

Table 3. The NSE values at the four runoff gauging stations.

\begin{tabular}{ccc}
\hline${ }^{\mathbf{b}}$ Runoff Gauging Station & Calibration Period (1980-1993) & Validation Period (1994-2000) \\
\hline Ankang & 0.93 & 0.83 \\
Baihe & 0.91 & 0.78 \\
Danjiangkou & 0.92 & 0.75 \\
Huangzhuang & 0.82 & 0.66 \\
\hline
\end{tabular}

${ }^{\mathrm{b}}$ The Ankang and Baihe stations are located in the upstream of the Hanjiang River, while the Danjiangkou and Huangzhuang stations are located in the mid-lower reaches of the Hanjiang River, respectively.

When the calibrated SWAT model is applied in both the historical period (1956-2016) and the future period (2020-2080), the amounts of local available water resources during a year, flood season (May-September) and non-flood season (January-April and OctoberDecember) in type A and type B areas can be estimated (listed in Table 4). The total annual available water resources will increase from 7.03 billion $\mathrm{m}^{3}$ in historical period to 8.01 billion $\mathrm{m}^{3}$ under RCP4.5 scenario due to the increasing precipitation. However, the available water resources in non-flood season will decrease from 1.76 billion $\mathrm{m}^{3}$ to 1.57 billion $\mathrm{m}^{3}$. Thus, the temporal distribution of available water resources will become more uneven. The available water resources in the type $C$ area are from the main stream of the Hanjiang River and are dependent on the inflow and the operational rule of the Danjiangkou reservoir. Figure 5 shows the percentage changes of the amount of available water resources under RCP4.5 scenario comparing to that under historical scenario. The available water resources in type A area will significantly increase with more than $10 \%$, while decreasing trends are found in type B area with a range from 5 to $10 \%$. As the geographic topography serves as a barrier to block the east monsoon winds going west, the precipitation is going to decrease in the west of mountain areas (i.e., type B area). The uneven spatial distribution of available water resources will be exacerbated by climate change according to the results of runoff projection in the future scenarios. 
Table 4. The water availability under the historical and future RCP4.5 scenarios (billion $\mathrm{m}^{3}$ ).

\begin{tabular}{ccccccc}
\hline Area & \multicolumn{2}{c}{ Type A } & \multicolumn{2}{c}{ Type B } & \multicolumn{2}{c}{ Total } \\
\hline Scenario & History & RCP4.5 & History & RCP4.5 & History & RCP4.5 \\
\hline Annual & 3.07 & 4.15 & 3.96 & 3.85 & 7.03 & 8.01 \\
Flood season & 2.29 & 3.23 & 2.98 & 3.20 & 5.27 & 6.43 \\
Non-flood season & 0.77 & 0.92 & 0.98 & 0.65 & 1.76 & 1.57 \\
\hline
\end{tabular}

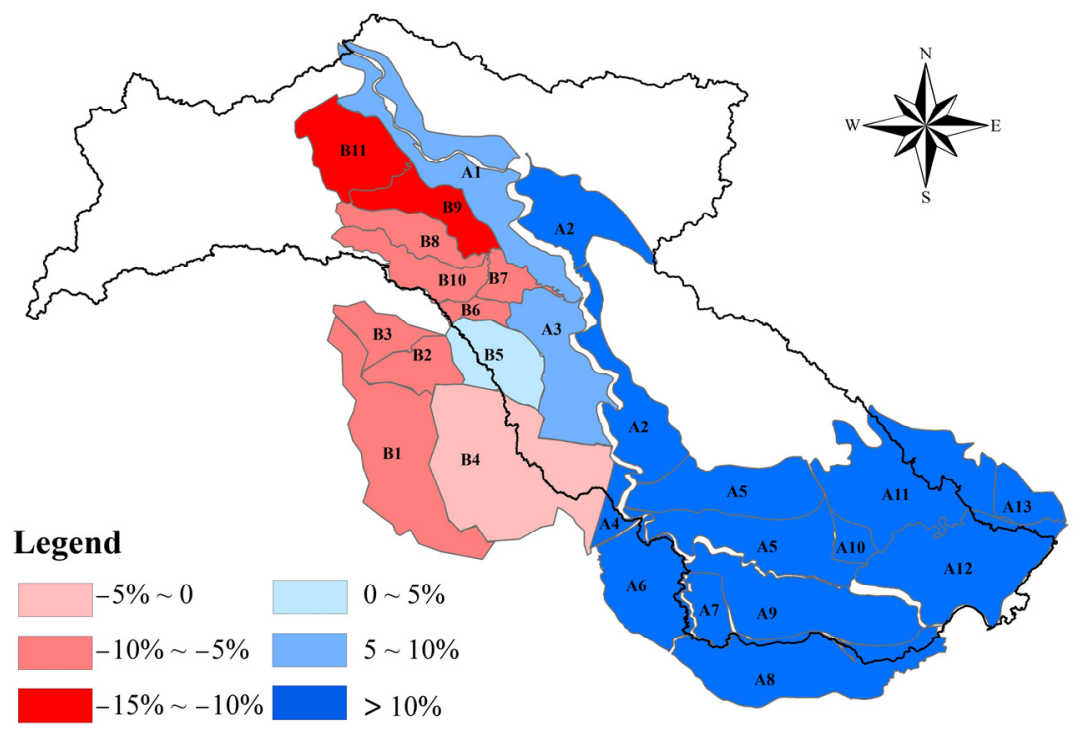

Figure 5. The percentage changes of available water resources under RCP4.5 scenario to the historical scenario in every operational zone (the blue indicates the increase while the red indicates the decrease).

\subsection{Water Demand in 2016 and 2030}

The water demands in 2016 and 2030 are estimated by the water demand projection module, with the results are listed in Table 5 . The percentages of water demand among socioeconomic water use are shown in Figure 6. The in-stream ecological water demand in every node has been estimated on basis of the runoff series outputted from the SWAT model. Figure 7a shows the in-stream ecological water demand in type A and type B areas. The in-stream ecological water demand in type $C$ is set as the same as the value in type $A$ at their sharing nodes. The Huangjiagang station (shown in Figure $7 \mathrm{~b}$ ) is set as a typical node at main stream of mid-lower reaches of the Hanjiang River for estimating the in-stream ecological water demand.

Table 5. Water demands of the socioeconomic water use in 2016 and 2030 (million $\mathrm{m}^{3}$ ).

\begin{tabular}{|c|c|c|c|c|c|c|}
\hline Scenario & Area & Municipal & Rural & Industrial & Agricultural & Total \\
\hline \multirow{4}{*}{2016} & type A & 136 & 135 & 808 & 5081 & 6160 \\
\hline & type B & 152 & 48 & 1075 & 2056 & 3331 \\
\hline & type C & 658 & - & 1584 & - & 2243 \\
\hline & Total & 946 & 184 & 3468 & 7137 & 11,734 \\
\hline \multirow{4}{*}{2030} & type A & 193 & 137 & 1389 & 4611 & 6330 \\
\hline & type B & 206 & 33 & 1918 & 1964 & 4122 \\
\hline & type C & 779 & - & 2666 & - & 3445 \\
\hline & Total & 1178 & 170 & 5973 & 6576 & 13,897 \\
\hline
\end{tabular}




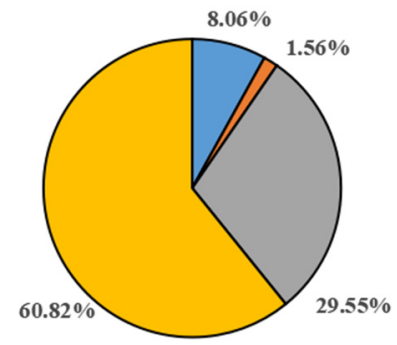

(a) 2016

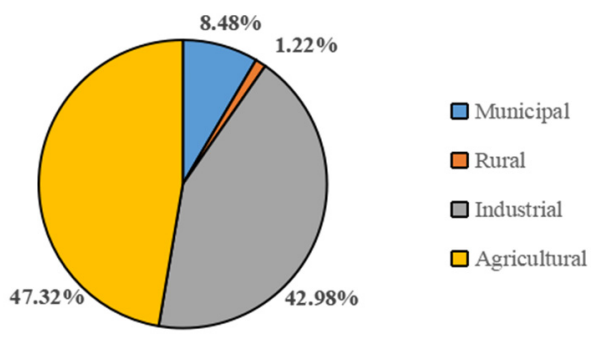

(b) 2030

Figure 6. The percentages of water demand for the socioeconomic water use in 2016 (a) and 2030 (b).

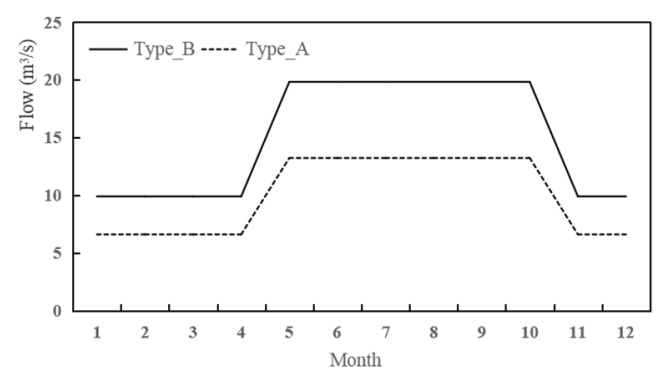

(a) The rivers in type A and type B areas

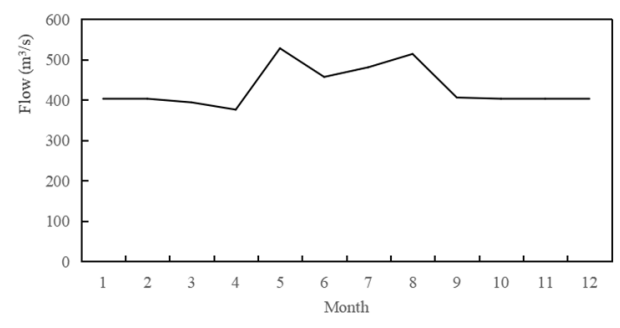

(b) Huangjiagang runoff station

Figure 7. The in-stream ecological flows (a) in type A, type B areas and (b)at the Huangjiagang runoff station.

The annual water demand will gradually increase from 11,734 million $\mathrm{m}^{3}$ in 2016 to 13,897 million $\mathrm{m}^{3}$ in 2030 (listed in Table 5). The municipal water demand increases from 946 million $\mathrm{m}^{3}$ (the percentage is $8.06 \%$, hereinafter the same) to 1178 million $\mathrm{m}^{3}(8.48 \%)$, while the rural water demand declines from 184 million $\mathrm{m}^{3}(1.56 \%)$ to 170 million $\mathrm{m}^{3}$ $(1.22 \%)$. The industrial water demand increases from 3467 million $\mathrm{m}^{3}(29.55 \%)$ to 5973 million $\mathrm{m}^{3}$ (42.98\%). Although the agricultural water demand slightly declines, it still occupies the largest percentage among the water uses (i.e., 60.82\% in 2016 and $47.32 \%$ in 2030). As the Hanjiang River basin is a pilot area for implementing the strictest water resources control system for water resources management policy in China, the water consumption will be restricted by this water use efficiency control policy. The water demand in agriculture thus decreases. However, water demand in industry still increases enormously, even taking the water-saving technologies into consideration due to the rapid social and economic development. Therefore, the water supply security for social economic sustainable development will be seriously challenged.

\subsection{Results of Water Resources Allocation Model under Climate Change}

According to the Water Resources Management Plan over Hanjiang River Basin [51], the water demand for domesticity and ecology should be firstly ensured. Priorities for the water use from high to low are assigned as municipal use, rural use, in-stream ecology use, industrial use and agricultural use, respectively. Taking ten days as the time step, the allocated water resources for water use sectors in operational zones are obtained from the outputs of the IRAS model. The results under the schemes I, II, III and IV are listed in Table 6. 
Table 6. Water resources allocation results of five types of water use (million $\mathrm{m}^{3}$ ).

\begin{tabular}{|c|c|c|c|c|c|c|c|}
\hline Schemes & Variables & Municipal & Rural & Industrial & Agricultural & In-Stream Ecology & Total \\
\hline \multirow{4}{*}{ Scheme I } & Demand & 946 & 184 & 3468 & 7137 & 609 & 12,343 \\
\hline & Supply & 944 & 182 & 3190 & 6441 & 609 & 11,367 \\
\hline & Deficit & 2 & 1 & 278 & 695 & 0 & 977 \\
\hline & Deficit rate & $0.20 \%$ & $0.70 \%$ & $8.02 \%$ & $9.74 \%$ & $0.03 \%$ & $7.91 \%$ \\
\hline \multirow{4}{*}{ Scheme II } & Demand & 1178 & 170 & 5973 & 6576 & 609 & 14,506 \\
\hline & Supply & 1171 & 168 & 5224 & 5699 & 609 & 12,871 \\
\hline & Deficit & 7 & 1 & 749 & 877 & 1 & 1635 \\
\hline & Deficit rate & $0.63 \%$ & $0.78 \%$ & $12.54 \%$ & $13.34 \%$ & $0.11 \%$ & $11.27 \%$ \\
\hline \multirow{4}{*}{ Scheme III } & Demand & 946 & 184 & 3468 & 7137 & 609 & 12,343 \\
\hline & Supply & 938 & 179 & 3095 & 6378 & 594 & 11,183 \\
\hline & Deficit & 9 & 4 & 373 & 759 & 15 & 1160 \\
\hline & Deficit rate & $0.90 \%$ & $2.33 \%$ & $10.76 \%$ & $10.64 \%$ & $2.51 \%$ & $9.40 \%$ \\
\hline \multirow{4}{*}{ Scheme IV } & Demand & 1178 & 170 & 5973 & 6576 & 609 & 14,506 \\
\hline & Supply & 1161 & 166 & 5107 & 5702 & 590 & 12,726 \\
\hline & Deficit & 17 & 4 & 866 & 874 & 19 & 1780 \\
\hline & Deficit rate & $1.48 \%$ & $2.35 \%$ & $14.49 \%$ & $13.29 \%$ & $3.13 \%$ & $12.27 \%$ \\
\hline
\end{tabular}

The total water deficits under the four schemes are $977,1635,1160,1780$ million $^{3}$, respectively. The amount of increasing available water resources in the future $\left(0.98\right.$ billion $\mathrm{m}^{3}$, from 7.03 billion $\mathrm{m}^{3}$ to 8.01 billion $\mathrm{m}^{3}$ ) is much less than the amount of dramatic increase

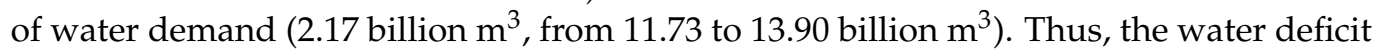
under future water demand scenario is obviously higher than that under historical scenario. Moreover, with the more uneven temporal-spatial distribution of available water resources under future water availability scenario (shown in Table 4 and Figure 5), more water stress will be directly exerted on reservoirs operation for increasing water supply. The risk of water deficit will increase (scheme III $(9.40 \%)>$ scheme I $(7.91 \%)$ and scheme IV $(12.27 \%)>$ scheme II $(11.27 \%))$. The water deficits are mainly found in industry and agriculture while the other water uses can be satisfied. The water deficit rates of agriculture are even less than those of industry (scheme III and scheme IV), although the industry has a higher priority. Because the water consumption in agriculture mainly happens in flood season (according to water demand projection results, the water demands from May to September occupy $80.49 \%$ and $78.87 \%$ in 2016 and 2030, respectively). Water demand in agriculture matches the inflow process fitly (shown in Table 4) and is effectively satisfied by natural water flow.

In order to analyze the spatial distribution of water deficit, the water deficit rates of every operational zone in type A and type B areas are presented in Figure 8. The water deficit rates are less than $1 \%$ in type $\mathrm{C}$ area and less than $5 \%$ in type $\mathrm{A}$ area. As the operational zones in type $\mathrm{A}$ and type $\mathrm{C}$ areas are located in the downstream of Danjiangkou reservoir, they can extract the water released from Danjiangkou reservoir. Even the water demand will dramatically increase in the scheme II and IV, there are few water deficits in these two type areas. However, water deficits in type B area are serious, as its water supply are only from the local available water resources and the local reservoirs without enough storages, which cannot meet their increasing demand. 


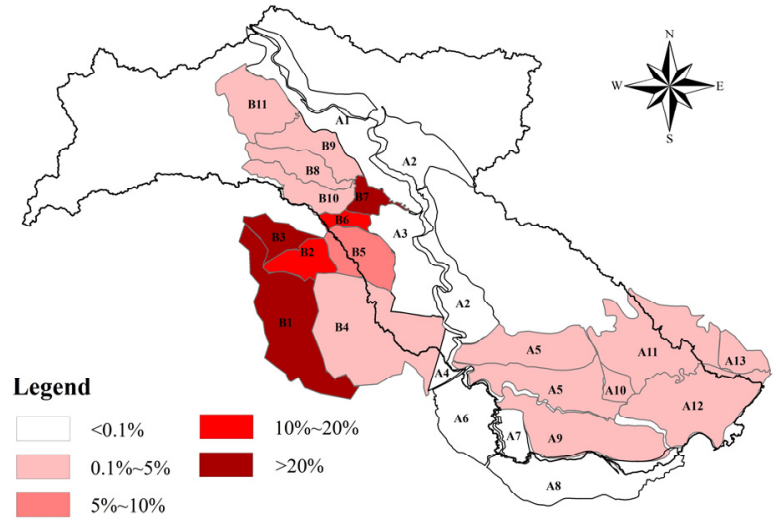

(a) Scheme I

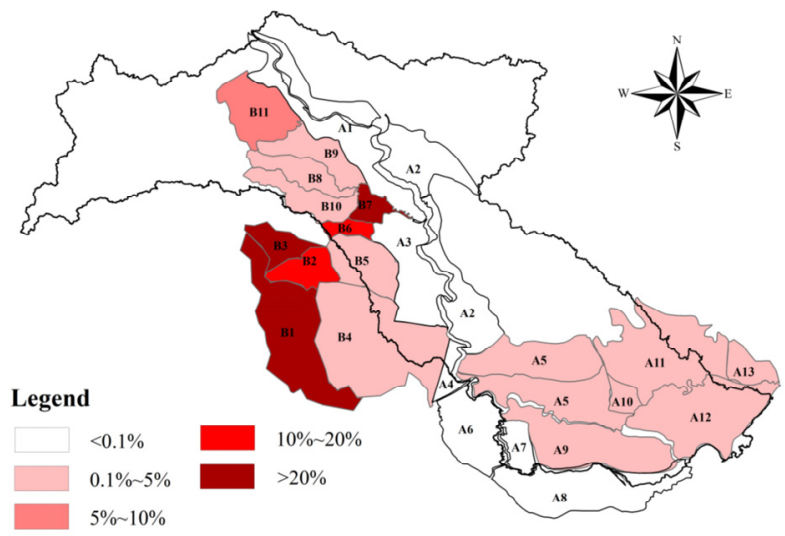

(c) Scheme III

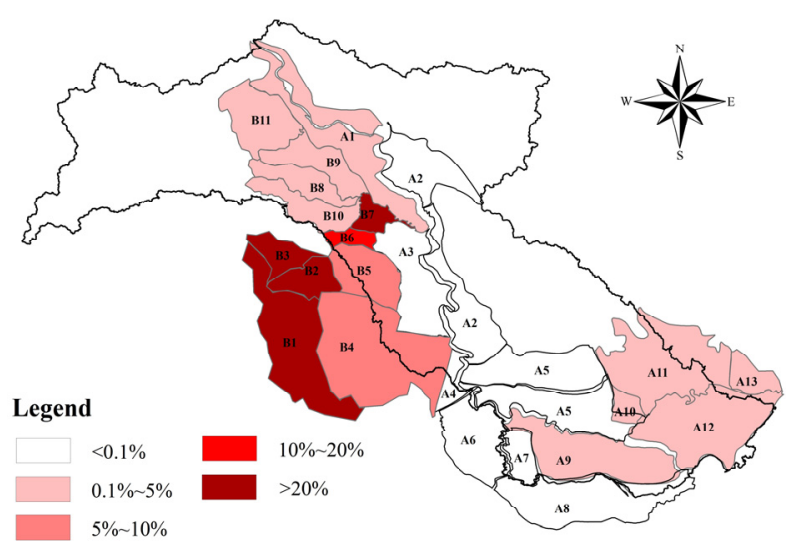

(b) Scheme II

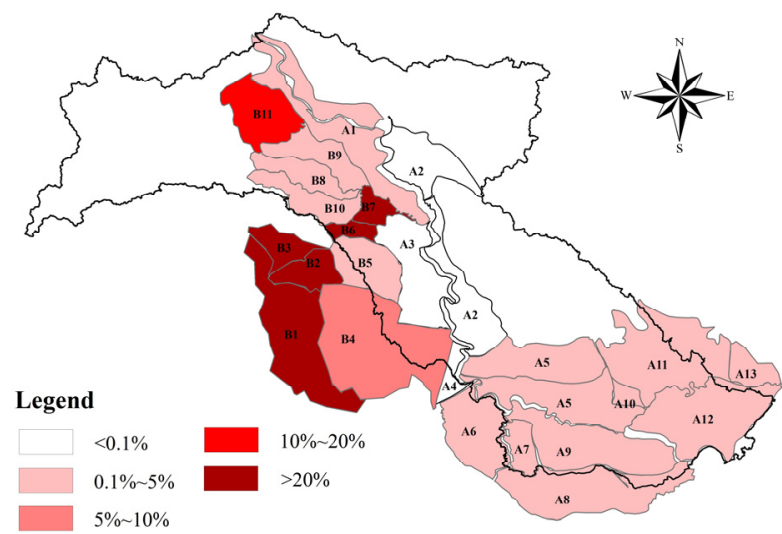

(d) Scheme IV

Figure 8. Spatial distribution of water deficit rates in operational zones under the schemes (a) I, (b) II, (c) III and (d) IV.

\subsection{Water Environmental Capacity Response to Water Resources Allocation under Climate Change}

There are two types of low water flow series. One is outputted from water resources allocation model. The other one is natural low water flow series. The designed low water flows are determined by frequency analysis on these two low water flow series. As the mainstream can be divided into eight river segments (shown in Figure 4), there are eight designed low water flows (listed in Table 7). The background concentrations for pollutants are set as the maximum value to meet their water protection targets (i.e., the class II in our study area according to the water environment function area in Hanjiang River basin). WEC in every segment is subsequently determined by the water environmental capacity determination module (listed in Table 8). To achieve water quality protection target, the permissible discharges of pollutants in these eight river segments can be estimated by deducting discharged pollutants from WECs as listed in Table 9. 
Table 7. The designed low water flows in eight river segments $\left(\mathrm{m}^{3} / \mathrm{s}\right)$.

\begin{tabular}{ccccccc}
\hline River Segment & Scheme I & Scheme II & Scheme III & Scheme IV & Scheme V & Scheme VI \\
\hline S1: Huangjiagang Jiangjiaying & 555 & 550 & 555 & 557 & 221 & 186 \\
S2: Jiangjiaying Yujiahu & 630 & 512 & 621 & 494 & 263 & 232 \\
S3: Yujiahu Huangzhuang & 635 & 513 & 622 & 497 & 263 & 235 \\
S4: Huangzhuang Shayang & 634 & 513 & 621 & 497 & 263 & 236 \\
S5: Shayang Zekou & 637 & 505 & 627 & 498 & 275 & 273 \\
S6: Zekou Yuekou & 634 & 504 & 621 & 496 & 266 & 230 \\
S7: Yuekou Xiantao & 684 & 534 & 625 & 502 & 257 & 226 \\
S8: Xiantao Hankou & 662 & 523 & 622 & 498 & 505 & 260 \\
Average value & 634 & 519 & 614 & & & 226 \\
\hline
\end{tabular}

Table 8. The WEC of $\mathrm{COD}_{\mathrm{Mn}}$ and $\mathrm{NH}_{3}-\mathrm{N}$ in eight river segments (t/a).

\begin{tabular}{|c|c|c|c|c|c|c|c|}
\hline Pollutant & Segment & Scheme I & Scheme II & Scheme III & Scheme IV & Scheme V & Scheme VI \\
\hline \multirow{9}{*}{$\mathrm{COD}_{\mathrm{Mn}}$} & S1: Huangjiagang Jiangjiaying & 38,329 & 37,906 & 38,329 & 38,499 & 20,953 & 19,741 \\
\hline & S2: Jiangjiaying Yujiahu & 158,948 & 138,636 & 157,390 & 135,565 & 100,412 & 95,220 \\
\hline & S3: Yujiahu Huangzhuang & 42,535 & 28,844 & 41,070 & 27,793 & 16,322 & 15,469 \\
\hline & S4: Huangzhuang Shayang & 60,067 & 45,259 & 58,474 & 43,305 & 32,341 & 30,361 \\
\hline & S5: Shayang Zekou & 69,918 & 54,787 & 68,772 & 53,984 & 45,599 & 42,857 \\
\hline & S6: Zekou Yuekou & 37,007 & 30,462 & 36,352 & 30,059 & 20,539 & 19,516 \\
\hline & S7: Yuekou Xiantao & 81,951 & 56,607 & 71,960 & 51,231 & 38,858 & 35,494 \\
\hline & S8: Xiantao Hankou & 59,667 & 42,703 & 54,778 & 39,661 & 29,274 & 26,978 \\
\hline & Total & 548,422 & 435,204 & 527,126 & 420,096 & 304,299 & 285,637 \\
\hline \multirow{9}{*}{$\mathrm{NH}_{3}-\mathrm{N}$} & S1: Huangjiagang Jiangjiaying & 746 & 737 & 746 & 749 & 404 & 379 \\
\hline & S2: Jiangjiaying Yujiahu & 2904 & 2519 & 2875 & 2461 & 1768 & 1663 \\
\hline & S3: Yujiahu Huangzhuang & 828 & 564 & 800 & 543 & 318 & 301 \\
\hline & S4: Huangzhuang Shayang & 1157 & 874 & 1127 & 837 & 617 & 578 \\
\hline & S5: Shayang Zekou & 1340 & 1050 & 1318 & 1035 & 857 & 800 \\
\hline & S6: Zekou Yuekou & 723 & 595 & 710 & 587 & 399 & 377 \\
\hline & S7: Yuekou Xiantao & 1565 & 1086 & 1376 & 984 & 735 & 670 \\
\hline & S8: Xiantao Hankou & 1152 & 827 & 1058 & 768 & 560 & 515 \\
\hline & Total & 10,414 & 8252 & 10,009 & 7964 & 5657 & 5283 \\
\hline
\end{tabular}

Table 9. ${ }^{c}$ The permissible $\mathrm{COD}_{\mathrm{Mn}}$ and $\mathrm{NH}_{3}-\mathrm{N}$ in eight river segments (t/a).

\begin{tabular}{|c|c|c|c|c|c|c|c|}
\hline Pollutant & Segment & Scheme I & Scheme II & Scheme III & Scheme IV & Scheme V & Scheme VI \\
\hline \multirow{9}{*}{$\mathrm{COD}_{\mathrm{Mn}}$} & S1: Huangjiagang Jiangjiaying & 33,025 & 32,602 & 33,025 & 33,194 & 15,649 & 14,437 \\
\hline & S2: Jiangjiaying Yujiahu & $-65,436$ & $-85,748$ & $-66,994$ & $-88,819$ & $-123,972$ & $-129,164$ \\
\hline & S3: Yujiahu Huangzhuang & 40,173 & 26,482 & 38,708 & 25,431 & 13,960 & 13,107 \\
\hline & S4: Huangzhuang Shayang & 59,632 & 44,824 & 58,039 & 42,870 & 31,906 & 29,926 \\
\hline & S5: Shayang Zekou & 69,557 & 54,426 & 68,411 & 53,623 & 45,238 & 42,496 \\
\hline & S6: Zekou Yuekou & 35,796 & 29,251 & 35,141 & 28,848 & 19,328 & 18,306 \\
\hline & S7: Yuekou Xiantao & 33,304 & 7960 & 23,313 & 2584 & -9789 & $-13,153$ \\
\hline & S8: Xiantao Hankou & 35,162 & 18,198 & 30,273 & 15,156 & 4769 & 2473 \\
\hline & Total & 241,213 & 127,995 & 219,917 & 112,887 & -2910 & $-21,572$ \\
\hline \multirow{9}{*}{$\mathrm{NH}_{3}-\mathrm{N}$} & S1: Huangjiagang Jiangjiaying & 591 & 583 & 591 & 594 & 249 & 224 \\
\hline & S2: Jiangjiaying Yujiahu & -3641 & -4026 & -3670 & -4085 & -4778 & -4882 \\
\hline & S3: Yujiahu Huangzhuang & 759 & 495 & 731 & 474 & 249 & 232 \\
\hline & S4: Huangzhuang Shayang & 1145 & 861 & 1114 & 824 & 604 & 565 \\
\hline & S5: Shayang Zekou & 1329 & 1040 & 1307 & 1024 & 846 & 789 \\
\hline & S6: Zekou Yuekou & 688 & 559 & 675 & 551 & 363 & 342 \\
\hline & S7: Yuekou Xiantao & 146 & -333 & -43 & -435 & -684 & -749 \\
\hline & S8: Xiantao Hankou & 437 & 112 & 343 & 54 & -155 & -200 \\
\hline & Total & 1453 & -709 & 1048 & -998 & -3304 & -3678 \\
\hline
\end{tabular}


The designed low water flows along the main streams under the six schemes are quite different. Specifically, the designed low water flows under the schemes I, III, V and VI have notably increased in the river segment S2 and then have fluctuated slightly in the downstream river segments. The designed low water flows under the schemes II and IV are found to significantly decline in the river segment S2. As the industrial city, Xiangyang, locates near the river segment S2 (shown in Figure 3) and its industrial water demand is going to enormously increase in 2030, large amount of water is extracted from the main stream to satisfy the demand all the year. Thus, the low water flow is reduced and then WECs decrease. The maximum WEC is also found in the river segment S2. Specifically,

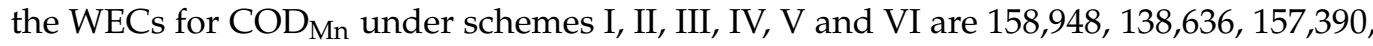
$135,565,100,412$ and 95,520 t/a, respectively. For $\mathrm{NH}_{3}-\mathrm{N}$, the WECs are 2904, 2519, 2875, 2461, 1768 and $1663 \mathrm{t} / \mathrm{a}$, respectively. However, as the discharged pollutants have exceeded its WEC in 2016, there are no more permissible $\mathrm{COD}_{\mathrm{Mn}}$ and $\mathrm{NH}_{3}-\mathrm{N}$. Similarly, no more permissible $\mathrm{NH}_{3}-\mathrm{N}$ have also been found in the river segment $\mathrm{S} 7$. Therefore, the pollution discharge should be reduced in the river segments S2 and S7.

To further investigate the impacts of the varied water availability and water demand conditions on the WEC, the percentage changes of WECs are calculated. Schemes I and III, II and IV as well as V and VI are paired to analyze the response to variation of water availability, while the schemes I and II as well as III and IV are paired to investigate the response to different water demand scenarios (shown in Figure 9). Three types of river segments are classified based on their WECs (shown in Figure 10). The river segment where the WEC is slightly responsive to the variations of water availability and water demand is defined as type (i). The river segment $\mathrm{S} 1$ is located in the reach between Huangjiagang and Jiangjiaying stations. The river segments S2, S3, S4, S5, S6 are taken as type (ii) where their WECs are sensitive to the changing water demand scenarios and not to the variation of water availability. These river segments are located in the reach between Jiangjiaying and Yuekou stations. The river segments S7 and S8, are defined as type (iii) where their WECs are sensitive to both the variations of water availability and water demand, and these two river segments are located between Yuekou and Wuhan stations.

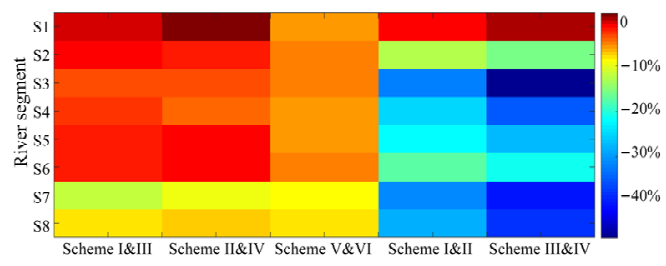

(a) $\mathrm{COD}_{\mathrm{Mn}}$

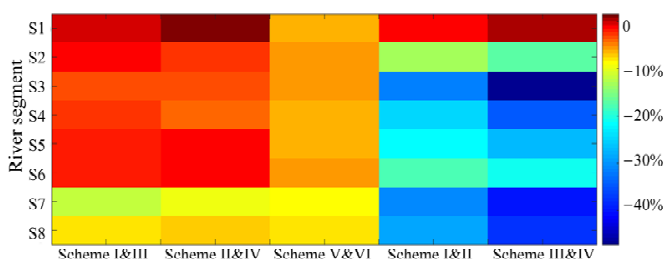

(b) $\mathrm{NH}_{3}-\mathrm{N}$

Figure 9. The WEC percentage changes between schemes under varied water availability and water demand conditions; (a) $\mathrm{COD}_{\mathrm{Mn}} ;(\mathbf{b}) \mathrm{NH}_{3}-\mathrm{N}$.

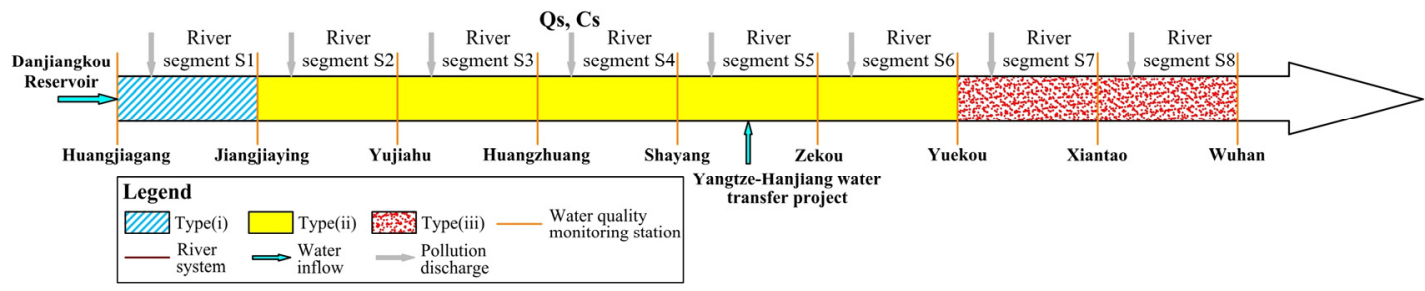

Figure 10. Three types of river segments along the main stream of the mid-lower reaches of the Hanjiang River.

\subsubsection{Impacts of Variations of Water Availability on Water Environmental Capacity}

The results from the reference schemes $\mathrm{V}$ and VI show that the average designed water flow has declined from $260 \mathrm{~m}^{3} / \mathrm{s}$ to $226 \mathrm{~m}^{3} / \mathrm{s}$. Due to more uneven temporal-spatial distribution of water availability in the future, there will be less available water resources in 
dry season (from November to next January), which leads to decreasing the designed low water flow. Thus, there will be notable declines of WEC and their percentage changes with range from 5.17 to $8.66 \%$ for $\mathrm{COD}_{\mathrm{Mn}}$ and from 5.36 to $8.85 \%$ for $\mathrm{NH}_{3}-\mathrm{N}$ (shown in Figure 9), respectively. More amounts of pollutants are required to be restricted from discharging into river system (from $2190 \mathrm{t} / \mathrm{a}$ to $21,572 \mathrm{t} / \mathrm{a}$ for $\mathrm{COD}_{\mathrm{Mn}}$ and from $3304 \mathrm{t} / \mathrm{a}$ to $3678 \mathrm{t} / \mathrm{a}$ shown in Table 9). Hence, WECs in every river segment from the schemes V and VI will decrease under future water availability scenario.

Water resources allocation for water demand can alter water availability. The WEC varies with the water availability conditions. In the river segments of type (i) and type (ii), WECs are resilient to the varied water availability conditions. The river segments S1, S2, S3, and $\mathrm{S} 4$ are located in the downstream of Danjiangkou reservoir while the river segments S5 and S6 are located in the downstream of Changjiang-Hanjiang Water Diversion Project (shown in Figures 3 and 10). There are abundant water resources and strong regulating capability of water projects in S1-S6 river segments. The negative impacts from the uneven temporal-spatial distribution of available water resources on low water flow series are effectively alleviated by water projects operation. Little differences can be found in the designed low water flows of these six river segments under the history and future water availability scenarios, ranging from $0 \mathrm{~m}^{3} / \mathrm{s}$ to $18 \mathrm{~m}^{3} / \mathrm{s}$ (listed in Table 7). Hence, there are little differences of WEC change percentages between schemes I and III, schemes II and IV. Even the maximum differences are even less than 5\% (i.e., $3.44 \%$ and $4.32 \%$ for $\mathrm{COD}_{\mathrm{Mn}}$ and $3.41 \%$ and $4.28 \%$ for $\mathrm{NH}_{3}-\mathrm{N}$ according to Figure 9 ). As the current pollution loads scenario in 2016 is simultaneously applied to the six schemes, there is no increasing pollutants discharge and little differences (less than $5 \%$ ) can be found in their corresponding permissible pollutants.

The river segments $\mathrm{S} 7$ and $\mathrm{S} 8$ of the type (iii) are located in the downstream of the main stream (shown in Figure 10), that is far away from Danjiangkou reservoir. There is only one middle size reservoir (i.e., median) for regulating water flow (shown in Figure 2). The water deficit will become more serious and will decrease low water flow series, especially in dry season, due to the more uneven temporal-spatial distribution of available water resources in the future. The designed low water flows will subsequently decrease. Thus, the WECs in $\mathrm{S} 7$ and $\mathrm{S} 8$ river segments will decrease under future water availability scenarios. The maximum decreases of WECs have even reached $12.19 \%$ for $\mathrm{COD}_{\mathrm{Mn}}$ and $12.04 \%$ for $\mathrm{NH}_{3}-\mathrm{N}$ in the river segments S7 and S8 of the type (iii) area, respectively (shown in Figure 9).

\subsubsection{Impacts of Water Demand Scenarios on Water Environmental Capacity}

The water sources for the cities Xiangyang (operational zones A1, A2, C2 and C6) and Jingmen (operational zones A3, A4, C7 and C16) are mainly from the river segments S2, S3, S4, S5 and S6 (shown in Figure 3). The river segments S7 and S8 are the primary water sources for the cities Xiantao (operational zones A9, A10, C10 and C11) and Wuhan (operational zones A11, A12, A13, C1 and C9) (shown in Figure 3). Their water demands in 2030 will substantially increase with the developments of industry and increasing population. More water will be extracted from these seven river segments (S2-S8) to satisfy their increasing water demands in the future. The designed low water flow series from the schemes III and IV with water demand in future scenarios are obviously lower than that from the schemes I and II. Even the minimum decreases in these river segments are more than $118 \mathrm{~m}^{3} / \mathrm{s}$ and $123 \mathrm{~m}^{3} / \mathrm{s}$ under schemes III and IV, respectively. Thus, their WECs have remarkably decreased (shown in Figure 9), the percentage decreases of which range from 12.78 to $47.77 \%$ for $\mathrm{COD}_{\mathrm{Mn}}$ and from 13.27 to $47.20 \%$ for $\mathrm{NH}_{3}-\mathrm{N}$. The permissible pollutants discharge is then going to decrease if the amount of pollutants discharge keeps the current level. Therefore, the water demand scenarios in the future will increase water deficits and decrease WECs.

However, there are no significant differences of WEC between the water demand scenarios in 2016 and 2030 in the river segment S1. The water demand along the river segment S1 (shown in Figure 3) occupies a very-small percentage of their available water 
resources, and the increasing amount of water demand can be satisfied through the Danjiangkou reservoir operation. Therefore, the low water flow series in the river segment S1 decreases slightly and there is no significant difference of the designed low water flows (less than $5 \mathrm{~m}^{3} / \mathrm{s}$, shown in Table 7). The percentage changes of WECs for both $\mathrm{COD}_{\mathrm{Mn}}$ and $\mathrm{NH}_{3}-\mathrm{N}$ are less than $1.5 \%$, and the impacts of increasing water demand on the permissible pollutants are slight with the amount of pollution loads at current level. Therefore, the increasing water demand does not guarantee the decrease of WEC, as the negative impacts can be effectively alleviated by reservoirs operation.

\subsubsection{Impacts of Water Resources Allocation on Water Environmental Capacity}

Due to the uneven temporal distribution of water resources, the available water resources in non-flood season only account for $25 \%$ and $20 \%$ under the history and future water availability scenarios, respectively (listed in Table 4). The designed low water flows under the reference schemes are found much smaller than those under water resources allocation schemes. The average designed low water flows of eight river segments under schemes V and VI are $260 \mathrm{~m}^{3} / \mathrm{s}$ and $226 \mathrm{~m}^{3} / \mathrm{s}$, while the average designed low water flows under schemes I, II, III and IV are $634 \mathrm{~m}^{3} / \mathrm{s}, 519 \mathrm{~m}^{3} / \mathrm{s}, 614 \mathrm{~m}^{3} / \mathrm{s}$ and $505 \mathrm{~m}^{3} / \mathrm{s}$, respectively. Even the minimum difference of the average designed low water flow is $245 \mathrm{~m}^{3} / \mathrm{s}$. As water resources allocation model can effectively regulate water flow through reservoirs operation, much water is stored in reservoirs in flood season and then is released to satisfy the water demand in dry season. Water demand are effectively assured. The low water flow series is notably increased and further results in the remarkable increase of designed low water flows. The increasing difference of the designed low water flows ranges from $230 \mathrm{~m}^{3} / \mathrm{s}$ (in the segment $\mathrm{S} 5$ under scheme II) to $418 \mathrm{~m}^{3} / \mathrm{s}$ (in the segment S7 under scheme I). Thus, WECs increase significantly. The increases of the total WEC under schemes I and II are 244,123 t/a, 130,905 t/a for $\mathrm{COD}_{\mathrm{Mn}}$ and $4757 \mathrm{t} / \mathrm{a}, 2595 \mathrm{t} / \mathrm{a}$ for $\mathrm{NH}_{3}-\mathrm{N}$, comparing with those under the reference scheme V (listed in Table 8). Similar results are also found between schemes III, IV and scheme VI. The increasing total WECs are 241,488 and 134,459 t/a for $\mathrm{COD}_{\mathrm{Mn}}$ and 4726 and $2680 \mathrm{t} / \mathrm{a}$ for $\mathrm{NH}_{3}-\mathrm{N}$, respectively. As the current pollution discharges under the schemes $\mathrm{V}$ and VI exceed the WECs, it is required to reduce by 2910 and 21,572 t/a for $\mathrm{COD}_{\mathrm{Mn}}$, and 3304 and $3678 \mathrm{t} / \mathrm{a}$ for $\mathrm{NH}_{3}-\mathrm{N}$. While the reservoirs operation in water resources allocation increases WEC feasibly, the exceeding parts of pollutants are significantly decreased under schemes I, II, III and IV. The reduction of the total amount of pollutants is only required for $\mathrm{NH}_{3}-\mathrm{N}$ under schemes II and IV (i.e., $709 \mathrm{t} / \mathrm{a}$ and $998 \mathrm{t} / \mathrm{a}$, respectively). Therefore, water resources allocation can regulate water flows to alleviate the negative impacts of uneven temporal-spatial distributions of water resources and can assure the water supply even in dry season. The designed low water flows will increase significantly and will further result in the remarkable increase of WEC.

\section{Conclusions}

As the low water flow series is disturbed by climate change as well as reservoirs operation and water acquisition, the stationarity assumption of low water flow series is disturbed and will probably bring risk to WEC planning. In order to figure out the impacts of climate change and water resources allocation in the form of water acquisition and reservoir operation on WEC, a useful framework incorporating water availability estimation module, water demand projection module, water resources allocation module and water environmental capacity determination module was proposed, which offers an effective tool for estimating WEC under nonstationary water flow conditions. The mid-lower reaches of the Hanjiang River basin in China were taken as a case study.

The more uneven temporal-spatial distribution of available water resources due to climate change will bring considerable challenges to WEC. The total available water resources will increase over the study area. However, its uneven temporal-spatial distribution as well as the increasing water demand in the future will bring more stress on water supply, especially in the area with large amount of water demand and weak local storage capacity 
of the water projects. The low water flow will decrease, which will result in the decreases of their WECs. However, in the areas with the adequate regulating capacities of water projects, little differences of WEC can be found under the varied water availability and water demand conditions. As the water flow is regulated by the water resources allocation model through the reservoirs operation, the uneven temporal-spatial distribution of the water resources is remarkably relieved. More water is stored to satisfy the water demand in the dry season through the reservoirs operation, significantly increasing the low water flow series to further increase the designed low water flow and also the WEC in these areas.

The uncertainties of the results from the proposed framework are not neglected. The uncertainties are not only from the modules themselves, but also from the processes in the connected modules. Specifically, the uncertainties from the climate change scenarios propagate into the calibrated hydrological model in the water availability estimation module. The uncertainties from the water demand projection module and the water resources allocation module can also impact the water environmental capacity determination. As the available water resources are the main driver to the water resources allocation model for determining low water flow for WEC, more attention should be paid to the water availability estimation module in the uncertainty analysis. However, the proposed framework and our research results will not only offer useful guidelines for local water resources management but also demonstrate the potential for effective application in other basins.

Author Contributions: Conceptualization, D.L. and Y.Z.; Methodology, Y.Z.; Software, Y.Z., J.Y., J.T. and L.D.; Data Curation, J.Z. and L.D.; Formal Analysis, Y.Z. and D.L.; Writing-Original Draft Preparation, Y.Z. and D.L.; Writing-Review and Editing, S.G., L.X., P.L. and D.L. All authors have read and agreed to the published version of the manuscript.

Funding: The authors gratefully acknowledge the financial support from the National Natural Science Foundation of China (Nos. 51879194 and 51579183). This work is also partly funded by the Ministry of Foreign Affairs of Denmark and administered by Danida Fellowship Centre (File number: 18-M01-DTU).

Institutional Review Board Statement: Not applicable.

Informed Consent Statement: Not applicable.

Data Availability Statement: Not applicable.

Conflicts of Interest: We declare that we do not have any commercial or associative interest that represents a conflict of interest in connection with the work submitted.

\section{References}

1. Arnell, N.W. Climate change and global water resources: SRES emissions and socio-economic scenarios. Glob. Environ. Chang. 2004, 14, 31-52. [CrossRef]

2. Rockström, J.; Falkenmark, M.; Karlberg, L.; Hoff, H.; Rost, S.; Gerten, D. Future water availability for global food production: The potential of green water for increasing resilience to global change. Water Resour. Res. 2009, 45, W00A12. [CrossRef]

3. Li, K.; Zhang, L.; Li, Y.; Zhang, L.; Wang, X. A three-dimensional water quality model to evaluate the environmental capacity of nitrogen and phosphorus in Jiaozhou Bay. Mar. Pollut. Bull. 2014, 91, 306-316. [CrossRef] [PubMed]

4. Pastresa, R.; Ciavattaa, S.; Cossarinib, G.; Solidorob, C. Sensitivity analysis as a tool for the implementation of a water quality regulation based on the Maximum Permissible Loads policy. Reliab. Eng. Syst. Saf. 2003, 79, 239-244. [CrossRef]

5. Chen, L.; Han, L.; Ling, H.; Wu, J.; Tan, J.; Chen, B.; Zhang, F.; Liu, Z.; Fan, Y.; Zhou, M.; et al. Allocating water environmental capacity to meet water quality control by considering both point and non-point source pollution using a mathematical model. Water 2019, 11, 900. [CrossRef]

6. Wang, Q.; Liu, R.; Men, C.; Guo, L.; Miao, Y. Temporal-spatial analysis of water environmental capacity based on the couple of SWAT model and differential evolution algorithm. J. Hydrol. 2019, 569, 155-166. [CrossRef]

7. Liu, D.; Zeng, Y.; Qin, Y.; Shen, Y.; Zhang, J. Water supply-water environmental capacity nexus in a saltwater intrusion area under nonstationary conditions. Water 2019, 11,346. [CrossRef]

8. Nnaji, G.A.; Huang, W.; Gitau, M.W.; Clark, C. Frequency analysis of minimum ecological flow and gage height in Suwannee River, Florida. J. Coast. Res. 2014, 68, 152-159. [CrossRef]

9. Cooley, D. Return periods and return levels under climate change. In Extremes in a Changing Climate; Springer: Dordrecht, The Netherlands, 2013; Volume 65, pp. 97-114. 
10. Du, T.; Xiong, L.; Xu, C.; Gippel, C.; Guo, S.; Liu, P. Return period and risk analysis of nonstationary low-flow series under climate change. J. Hydrol. 2015, 527, 234-250. [CrossRef]

11. Rootzén, H.; Katz, R.W. Design Life Level: Quantifying risk in a changing climate. Water Resour. Res. 2013, 49, 5964-5972. [CrossRef]

12. Obeysekera, J.; Salas, J.D. Frequency of eecurrent extremes under nonstationarity. J. Hydrol. Eng. 2016, 21, 04016005. [CrossRef]

13. Chiew, F.H.S.; Teng, J.; Vaze, J.; Post, D.A.; Perraud, J.M.; Kirono, D.G.C.; Viney, N.R. Estimating climate change impact on runoff across southeast Australia: Method, results, and implications of the modeling method. Water Resour. Res. 2009, 45. [CrossRef]

14. Sharma, D.; Babel, M.S. Assessing hydrological impacts of climate change using bias-corrected downscaled precipitation in Mae Klong basin of Thailand. Meteorol. Appl. 2018, 25, 384-393. [CrossRef]

15. Chen, J.; Brissette, F.P.; Liu, P.; Xia, J. Using raw regional climate model outputs for quantifying climate change impacts on hydrology. Hydrol. Process. 2017, 31, 4398-4413. [CrossRef]

16. Yin, J.; Gentine, P.; Zhou, S.; Sullivan, S.; Wang, R.; Zhang, Y.; Guo, S. Large increase in global storm runoff extremes driven by climate and anthropogenic changes. Nat. Commun. 2018, 9, 4389. [CrossRef] [PubMed]

17. Liu, D.; Guo, S.; Shao, Q.; Liu, P.; Xiong, L.; Wang, L.; Hong, X.; Xu, Y.; Wang, Z. Assessing the effects of adaptation measures on optimal water resources allocation under varied water availability conditions. J. Hydrol. 2018, 556, 759-774. [CrossRef]

18. Yin, J.; Guo, S.; Gentine, P.; Sullivan, S.C.; Gu, L.; He, S.; Chen, J.; Liu, P. Does the Hook Structure Constrain Future Flood Intensification under Anthropogenic Climate Warming? Water Resour. Res. 2021, 57, e2020WR028491. [CrossRef]

19. Loucks, D.P. From analyses to implementation and innovation. Water 2020, 12, 974. [CrossRef]

20. Kirby, J.M.; Mainuddin, M.; Mpelasoka, F.; Ahmad, M.D.; Palash, W.; Quadir, M.E.; Shah-Newaz, S.M.; Hossain, M.M. The impact of climate change on regional water balances in Bangladesh. Clim. Chang. 2016, 135, 481-491. [CrossRef]

21. Nepal, S. Impacts of climate change on the hydrological regime of the Koshi river basin in the Himalayan region. J. Hydro-Environ. Res. 2016, 10, 76-89. [CrossRef]

22. Gu, J.J.; Huang, G.H.; Guo, P.; Shen, N. Interval multistage joint-probabilistic integer programming approach for water resources allocation and management. J. Environ. Manag. 2013, 128, 615-624. [CrossRef]

23. Jiang, C.; Xiong, L.; Xu, C.-Y.; Guo, S. Bivariate frequency analysis of nonstationary low-flow series based on the time-varying copula. Hydrol. Process. 2015, 29, 1521-1534. [CrossRef]

24. Vörösmarty, C.J.; Green, P.; Salisbury, J.; Lammers, R.B. Global water resources vulnerability from climate change and population growth. Science 2000, 289, 284-288. [CrossRef] [PubMed]

25. Mekonnen, M.M.; Hoekstra, A.Y. Four billion people facing severe water scarcity. Sci. Adv. 2016, 2, e1500323. [CrossRef] [PubMed]

26. Khare, D.; Jat, M.K.; Sunder, J.D. Assessment of water resources allocation options: Conjunctive use planning in a link canal command. Resour. Conserv. Recycl. 2007, 51, 487-506. [CrossRef]

27. He, S.; Guo, S.; Yang, G.; Chen, K.; Liu, D.; Zhou, Y. Optimizing Operation Rules of Cascade Reservoirs for Adapting Climate Change. Water Resour. Manag. 2019, 34, 101-120. [CrossRef]

28. Tian, J.; Liu, D.; Guo, S.; Pan, Z.; Hong, X. Impacts of inter-basin water transfer projects on optimal water resources allocation in the Hanjiang River basin, China. Sustainability 2019, 11, 2044. [CrossRef]

29. Vörösmarty, C.J.; McIntyre, P.B.; Gessner, M.O.; Dudgeon, D.; Prusevich, A.; Green, P.; Glidden, S.; Bunn, S.E.; Sullivan, C.A.; Liermann, C.R.; et al. Global threats to human water security and river biodiversity. Nature 2010, 467, 555-561. [CrossRef]

30. Pablo, B.G.; Patricia, J.S.; Javier, S.A.; Julio, P.S. Impact of climate change on water balance components and droughts in the Guajoyo River Basin (El Salvador). Water 2019, 11, 2360. [CrossRef]

31. Zhang, C.; Huang, Y.; Javed, A.; Arhonditsis, G.B. An ensemble modeling framework to study the effects of climate change on the trophic state of shallow reservoirs. Sci. Total Environ. 2019, 697, 134078. [CrossRef]

32. Chen, J.; Brissette, F.P.; Chaumont, D.; Braun, M. Finding appropriate bias correction methods in downscaling precipitation for hydrologic impact studies over North America. Water Resour. Res. 2013, 49, 4187-4205. [CrossRef]

33. Shabani, S.; Candelieri, A.; Archetti, F.; Naser, G. Gene expression programming coupled with unsupervised learning: A two-stage learning process in multi-scale, short-term water demand forecasts. Water 2018, 10, 142. [CrossRef]

34. Tennant, D.L. Instream flow regimens for fish, wildlife, recreation and related environmental resources. Fisheries 1976, 1 , 6-10. [CrossRef]

35. Matrosov, E.S.; Harou, J.J.; Loucks, D.P. A computationally efficient open-source water resource system simulator-Application to London and the Thames Basin. Environ. Modell. Softw. 2011, 26, 1599-1610. [CrossRef]

36. Wang, Y.; Yang, J.; Chang, J. Development of a coupled quantity-quality-environment water allocation model applying the optimization-simulation method. J. Clean. Prod. 2019, 213, 944-955. [CrossRef]

37. Douglas-Mankin, K.R.; Srinivasan, R.; Arnold, J.G. Soil and Water Assessment Tool (SWAT) model: Current developments and applications. Trans. ASABE 2010, 53, 1423-1431. [CrossRef]

38. Francesconi, W.; Srinivasan, R.; Pérez-Miñana, E.; Willcock, S.P.; Quintero, M. Using the Soil and Water Assessment Tool (SWAT) to model ecosystem services: A systematic review. J. Hydrol. 2016, 535, 625-636. [CrossRef]

39. Mango, L.M.; Melesse, A.M.; McClain, M.E.; Gann, D.; Setegn, S.G. Land use and climate change impacts on the hydrology of the upper Mara River Basin, Kenya: Results of a modeling study to support better resource management. Hydrol. Earth Syst. Sci. 2011, 15, 2245-2258. [CrossRef]

40. Pan, S.; Liu, D.; Wang, Z.; Zhao, Q.; Zou, H.; Hou, Y.; Liu, P.; Xiong, L. Runoff responses to climate and land use/cover changes under future scenarios. Water 2017, 9, 475. [CrossRef] 
41. Johnson, F.; Sharma, A. Measurement of GCM skill in predicting variables relevant for hydroclimatological assessments. J. Clim. 2009, 22, 4373-4382. [CrossRef]

42. Sanderson, B.M.; Oleson, K.W.; Strand, W.G.; Lehner, F.; O’Neill, B.C. A new ensemble of GCM simulations to assess avoided impacts in a climate mitigation scenario. Clim. Chang. 2015, 146, 303-318. [CrossRef]

43. Brekke, L.D.; Larsen, M.D.; Ausburn, M.; Takaichi, L. Suburban water demand modeling using stepwise regression. J. Am. Water Works Ass. 2002, 94, 65-75. [CrossRef]

44. Caissie, D.; El-Jabi, N. Comparison and regionalization of hydrologically based instream flow techniques in Atlantic Canada. Can. J. Civ. Eng. 1995, 22, 235-246. [CrossRef]

45. Loucks, D.P. Interactive River-Aquifer Simulation and Stochastic Analyses for Predicting and Evaluating the Ecologic Impacts of Alternative Land and Water Management Policies; Kluwer Academic Publishers: Dordrecht, The Netherlands, 2002; pp. 169-194.

46. Yang, G.; Guo, S.; Liu, P.; Li, L.P.; Liu, Z. Multiobjective cascade reservoir operation rules and uncertainty analysis based on PA-DDS algorithm. J. Water Resour. Plan. Manag. 2017, 143, 04017025. [CrossRef]

47. Xin, X.; Wu, T.; Li, J.; Wang, Z.; Li, W.; Wu, F. How well does BCC_CSM11 reproduce the 20th century climate change over China. Atmos. Ocean. Sci. Lett. 2013, 6, 21-26.

48. Hubei Provincial Department of Water Resources (HPDWR). Dispatching Schedules of Hubei Provincial Large Reservoirs; Hubei Provincial Department of Water Resources (HPDWR): Wuhan, China, 2014. (In Chinese)

49. Hubei Environmental Protection Bureau (HEPB). Ecological Environment Problems in the Middle and Lower Reaches of Hanjiang River; Hubei Environmental Protection Bureau (HEPB): Wuhan, China, 2018. (In Chinese)

50. Chinese Academy for Environmental Planning (CAEP). The Technical Key Points of Environmental Capacity of Surface Water in China; Chinese Academy for Environmental Planning (CAEP): Beijing, China, 2004. (In Chinese)

51. Changjiang Water Resources Commission (CWRC). Integrated Water Resources Planning of Hanjiang River Basin; Changiang Water Resources Commission (CWRC): Wuhan, China, 2016. (In Chinese) 